\title{
Comparison of Selenite and Selenate Apparent Absorption and Retention in Infants Using Stable Isotope Methodology
}

\author{
PETER VAN DAEL, LENA DAVIDSSON, EKHARD E. ZIEGLER, LAURENT B. FAY, AND \\ DENIS BARCLAY \\ Nestlé Research Center [P.V.D, L.D., L.B.F., D.B], Vers-chez-les-Blanc, CH-1000 Lausanne, Switzerland; \\ and Fomon Infant Nutrition Unit [E.E.Z], Department of Pediatrics, University of Iowa, Iowa City, Iowa, U.S.A.
}

\begin{abstract}
The inorganic selenium compounds selenite and selenate are used for selenium fortification of infant formulas. However, information on absorption and retention of selenium from these compounds is lacking. The purpose of this study was therefore to determine apparent absorption and retention of selenium from selenate and selenite added to a milk-based infant formula in healthy infants. Labeled test meals were prepared by addition of $10 \mu \mathrm{g} \mathrm{Se}$ as ${ }^{76} \mathrm{Se}$-selenate or ${ }^{74} \mathrm{Se}$-selenite to $500 \mathrm{~mL}$ formula. The two batches of labeled formulas were fed as alternate feeds during the first day of the balance period, followed by unlabeled formula. Selenium isotopes were determined in feces collected for $72 \mathrm{~h}$ after intake and in 3 consecutive $24 \mathrm{~h}$ collections of urine. Mean apparent absorption was $97.1 \%$ for ${ }^{76}$ Se-selenate and $73.4 \%$ for ${ }^{74} \mathrm{Se}$-selenite; mean difference $23.7 \%$ (range: $13.8 \%$ $35.7 \%$; SD 6.8\%, $p<0.001)$. Mean urinary excretion $(\%$ of ingested dose) was $36.4 \%\left({ }^{76} \mathrm{Se}\right.$-selenate) and $9.7 \%\left({ }^{74} \mathrm{Se}-\right.$ selenite); mean difference $26.7 \%$ (range: $13.9 \%-36.5 \%$; SD $5.9 \%, p<0.001)$. Mean apparent retention of selenium from
\end{abstract}

\section{ABSTRACT}

${ }^{76} \mathrm{Se}$-selenate and ${ }^{74} \mathrm{Se}$-selenite was not significantly different, $60.7 \%$ ( ${ }^{76} \mathrm{Se}$-selenate) versus $63.7 \%$ (for ${ }^{74} \mathrm{Se}$-selenite). The average difference was $-3.01 \%$ (range: $-14.0 \%-12.0 \%$; SD $9.4 \%, p=0.36$ ). Although apparent selenium absorption and urinary excretion differed for selenite and selenate, selenium was equally well retained by infants from both selenium compounds. We therefore concluded that Se fortification of infant formulas with selenate or selenite can be expected to have similar impact on the selenium nutritional status of term infants.(Pediatr Res 51: 71-75, 2002)
Abbreviations
GC-MS, gas chromatography mass spectrometry
GPx, glutathione peroxidase
HGAAS, hydride generation atomic absorption spectrometry
ID, iodothyronine deiodinase
Se, selenium

Selenium is an essential trace element for humans $(1,2)$. Biochemical evidence for its importance is demonstrated by its function in the selenoenzymes GPx, which protects cells against oxidative damage, ID, which catalyzes the conversion of $T_{4}$ into $T_{3}(3)$, and thioredoxin reductase, which plays a role in maintaining the redox environment of the cell $(3,4)$. Several other selenoproteins, such as selenoprotein $\mathrm{P}$, have been identified, but clear evidence for their biologic function is lacking (5). Recent observations on the role of selenium in the emergence of viral mutations (6) and the impact of selenium supplementation on the incidence of certain cancers (7) add more evidence to its importance for human health.

Although selenium deficiency has not been observed in healthy term infants, infants may be at risk of deficiency when fed formulas with naturally low selenium content (8). Selenium re-

Received December 4, 2000; accepted July 13, 2001

Correspondence and reprint request to: Laurent B. Fay, PhD, Nestlé Research Center, P.O. Box 44, Vers-chez-les-Blanc, CH-1000 Lausanne, Switzerland; e-mail: laurent-bernard.fay@rdls.nestle.com quirements during infancy are not well established. The World Health Organization recommends that infants consume $6 \mu \mathrm{g}$ Se/d during the first 6 mo of life (2), whereas the U.S. Food and Nutrition Board set the Recommended Dietary Allowance at 10 $\mu \mathrm{g} / \mathrm{d}$ for this age group (1). The selenium content of infant formulas without added selenium has been reported to be lower than that of human milk (6-12). Differences in selenium status between breast-fed and formula-fed infants may reflect the difference in selenium content, but may also indicate better selenium absorption from human milk (13-15).

Fortification of infant formulas with selenite or selenate, the only currently approved compounds for selenium fortification of infant formulas, has been shown to improve the selenium status of formula-fed infants (14-18). Selenium bioavailability, using selenite as an extrinsic stable isotope tracer, has previously been studied in preschool children (18) and very low birthweight infants (19), but to date there are no data comparing selenite and selenate apparent absorption and retention in healthy term infants. 
The aim of the present study was to compare apparent absorption and retention of selenium in term infants fed infant formula with added selenite and selenate.

\section{METHODS}

Subjects. Nine healthy term infants (3 females, 6 males) living in or around Iowa City, IA, U.S.A. participated in the study. Their age at the time of the study ranged from 64 to $198 \mathrm{~d}$ and their body weight varied from $4.69 \mathrm{~kg}$ to $7.93 \mathrm{~kg}$. All infants were formula-fed before enrollment into the study. Infants were admitted to the Lora N. Thomas Metabolic Unit, Iowa City, for the study (4 days). The study protocol was reviewed and approved by the University of Iowa Committee on Research Involving Human Subjects. The study procedures were explained to both parents and written consent was obtained.

Experimental design. The study formula, a commercially available milk-based infant formula (Carnation Follow-Up ${ }^{\mathbb{B}}$, Carnation, Glendale, CA, U.S.A.) provided $32.5 \mathrm{~g}$ protein, $26.6 \mathrm{~g}$ fat, and $85.6 \mathrm{~g}$ carbohydrate per liter. The formula contained no added selenium, and its selenium concentration was $0.16 \mu \mathrm{mol} \mathrm{Se} / \mathrm{L}$. Labeled formula was prepared by the addition of $10 \mu \mathrm{g} \mathrm{Se}$ as ${ }^{74} \mathrm{Se}$-selenite or ${ }^{76} \mathrm{Se}$-selenate to 500 $\mathrm{mL}$ formula about $15 \mathrm{~h}$ before use. The labeled formulas were stored at $4{ }^{\circ} \mathrm{C}$ until used.

The study formula without added stable isotope labels was fed to each infant for at least one week before the start of the study. The two $500 \mathrm{~mL}$ formula batches, labeled with ${ }^{74} \mathrm{Se}-$ selenite and ${ }^{76} \mathrm{Se}$-selenate, respectively, were fed in alternation during the initial day of the balance study until all labeled formula was consumed. The order of the labeled formulas was alternated between the infants. During the remainder of the balance study, unlabeled formula was used. Intake of labeled and unlabeled formulas was determined by weighing feeding bottles before and after feeding. Regurgitated formula was collected with preweighed wipes and subtracted. Urine and feces were collected quantitatively for $72 \mathrm{~h}$ using metabolic beds.

Stable isotope labels. Highly enriched elemental ${ }^{74} \mathrm{Se}$ $\left(98.2 \%{ }^{74} \mathrm{Se}, 1.8 \%{ }^{76} \mathrm{Se},<0.1 \%\right.$ other $\mathrm{Se}$ isotopes $),{ }^{76} \mathrm{Se}(1.2 \%$ ${ }^{74} \mathrm{Se}, 98.5 \%{ }^{76} \mathrm{Se}, 0.2 \%{ }^{77} \mathrm{Se},<0.03 \%$ other Se isotopes) and ${ }^{82} \mathrm{Se}\left(0.06 \%{ }^{74} \mathrm{Se}, 0.62 \%{ }^{76} \mathrm{Se}, 0.56 \%{ }^{77} \mathrm{Se}, 1.76 \%{ }^{78} \mathrm{Se}, 4.8 \%\right.$ ${ }^{80} \mathrm{Se}, 92.2 \%{ }^{82} \mathrm{Se}$ ) were purchased from Isotec (St-Quentin, France) and converted into ${ }^{74} \mathrm{Se}$-selenite, ${ }^{76} \mathrm{Se}$-selenate, and ${ }^{82} \mathrm{Se}$-selenite. Selenite was prepared by dissolving a precise amount of elemental Se (approximately $2.5-10 \mathrm{mg}$; weighed on a high precision analytical balance) into $1 \mathrm{~mL}$ of concentrated nitric acid. The solution was heated for $1 \mathrm{~h}$ at $60^{\circ} \mathrm{C}$ under nitrogen flow. The clear solution (approximately $0.2 \mathrm{~mL}$ ) was made up to $20 \mathrm{~mL}$ with deionized water, filtered through a 0.22 $\mu \mathrm{m}$ Teflon filter, and stored at $4^{\circ} \mathrm{C}$. Selenate labels were prepared from the selenite solution after evaporation to dryness at $100^{\circ} \mathrm{C}$ under nitrogen flow. Five $\mathrm{mL}$ of hydrogen peroxide were added to the white precipitate to oxidize selenite. The solution was slowly heated to $70^{\circ} \mathrm{C}$ and $0.2 \mathrm{~mL}$ of $2 \mathrm{M}$ potassium hydroxide was added. The volume was reduced under nitrogen flow to about $1 \mathrm{~mL}$ at $70^{\circ} \mathrm{C}$ and the oxidation step repeated three times. The solution was evaporated to dryness, the white precipitate re-dissolved in deionized water, and $0.1 \mathrm{~mL}$ concentrated nitric acid was added. Finally, the solution was made up to $20 \mathrm{~mL}$, filtered through a $0.22 \mu \mathrm{m}$ Teflon filter, and stored at $4^{\circ} \mathrm{C}$.

Speciation of selenite and selenate stable isotope solutions was performed by continuous flow HGAAS based on the principle that only selenite, but not selenate, can be directly measured by HGAAS upon reaction with a sodium borohydride reductant solution (20).

Determination of selenate by HGAAS requires a hydrochloric acid reduction step before HGAAS analysis. For each isotope, stock solutions containing $1.27 \mathrm{mmol} \mathrm{Se} / \mathrm{L}$ in $0.01 \mathrm{M}$ $\mathrm{HNO}_{3}$ were prepared.

Sample collection and handling. Fecal material and urine were collected separately for $72 \mathrm{~h}$ as described by Fomon (21). Carmine red was used as a fecal marker to determine the startand end-point of the fecal collection. Carmine red powder (50 $\mathrm{mg}$ ) was added to a small portion of the first labeled test meal and the second dose of carmine red was fed $72 \mathrm{~h}$ later. All fecal material was collected and included in the pooled fecal material for analysis of total Se and Se stable isotopes, from the first appearance of carmine red until but not including feces colored by the second dose of carmine red. Postbalance fecal samples were collected immediately after completion of the $72 \mathrm{~h}$ balance period. Urine was collected in $24 \mathrm{~h}$ pools. Pre and postbalance spot fecal samples were also collected. Capillary blood samples $(0.5 \mathrm{~mL})$ were collected in heparinized tubes before the start of the study for assessment of selenium status. Erythrocytes and plasma were separated by centrifugation $(2,500 \times$ $g, 15 \mathrm{~min}, 4^{\circ} \mathrm{C}$ ) and stored at $-80^{\circ} \mathrm{C}$. All samples were shipped on dry ice to the Nestlé Research Center and stored at $-40^{\circ} \mathrm{C}$ until analyzed.

Analytical methods. Total selenium levels and stable isotope ratios in samples of feces and urine were determined by GC-MS (22). Urine and fecal samples were acid digested using a mixture of nitric/perchloric acid (3:1) followed by the addition of hydrochloric acid to convert all selenium into selenite, which was then derivatized with 4-nitrophenylene-diamine to form the volatile piazselenole before analysis by GC-MS. Total selenium was determined by isotope dilution GC-MS using a ${ }^{82} \mathrm{Se}$-selenite spike. The selenium analysis was validated against a standard reference material (SRM) NIST 2670 toxic metals in freeze-dried urine [National Institute of Standards and Technology (NIST), Gaithersburg, MD, U.S.A.].

Plasma and erythrocyte selenium concentrations were determined by continuous flow HGAAS (20) and expressed as $\mu \mathrm{mol}$ $\mathrm{Se} / \mathrm{L}$ and nmol Se/ $\mu$ mol hemoglobin $(\mathrm{Hb})$, respectively. Se analyses were validated against commercial whole blood and serum quality control material (Seronorm: trace elements whole blood batch no. 030016; serum batch no. 010017; Nycomed, Oslo, Norway). Hb was analyzed by the standard cyanomethemoglobin technique.

Plasma and erythrocyte GPx activity were determined according to Belsten and Smith (23) and expressed per mg protein and per $\mu \mathrm{mol} \mathrm{Hb}$, respectively. Plasma protein levels were determined using the Pierce BCA colorimetric method (Rockford, IL, U.S.A.). 
Calculation of apparent selenium absorption and retention. Absorption and retention of the selenium stable isotope labels were calculated according to Turnlund et al. (24). Apparent absorption of ${ }^{74} \mathrm{Se}$ and ${ }^{76} \mathrm{Se}$ was calculated as the difference between the administered dose and the amount of isotope excreted in feces. Apparent retention of ${ }^{74} \mathrm{Se}$ and ${ }^{76} \mathrm{Se}$ was determined based on apparently absorbed isotope minus urinary excretion of selenium stable isotopes during $72 \mathrm{~h}$. Apparent absorption of total selenium (added stable isotope labels of selenium plus native selenium) from the formula was calculated using the classical chemical balance approach as the difference between total selenium intake and total fecal excretion during the $72 \mathrm{~h}$ balance period. Similarly, apparent retention of total selenium from the formula was calculated as total selenium apparent absorption minus total urinary selenium excretion during the $72 \mathrm{~h}$ balance.

Statistical analyses. The statistical significance was assessed by two-way ANOVA, with isotope and order of administration as factors (25). All computations are performed using S-PLUS 2000, release 2 (Mathsoft Inc., Seattle, WA, U.S.A.).

\section{RESULTS}

Subject's selenium status. Baseline values (mean $\pm \mathrm{SD}$ ) of Se status parameters were plasma Se, $0.84 \pm 0.17 \mu \mathrm{mol} \mathrm{Se} / \mathrm{L}$ (range: $0.64-1.16$ ); erythrocyte Se, $0.333 \pm 0.109 \mathrm{nmol} \mathrm{Se} /$ $\mu \mathrm{mol} \mathrm{Hb}$ (range: $0.239-0.534$ ); plasma GPx, $10.1 \pm 1.4 \mathrm{nmol}$ $\mathrm{NADPH} / \mathrm{min}$ (range: 8.0-11.8); and erythrocyte GPx, $1.25 \pm$ $0.18 \mathrm{nmol} \mathrm{NADPH} / \mathrm{min} \mathrm{g} \mathrm{Hb}$ (range: $1.00-1.50$ ).

Isotope balance data. During the $72 \mathrm{~h}$ balance period, the mean $( \pm \mathrm{SD})$ total intake of infant formula (labeled plus unlabeled) was $3133 \pm 403 \mathrm{~g}$. Intake of labeled formula was completed in $17.9 \pm 5.1 \mathrm{~h}\left({ }^{74} \mathrm{Se}\right.$-selenite $)$ and $18.8 \pm 5.4 \mathrm{~h}$ $\left({ }^{76} \mathrm{Se}\right.$-selenate). Mean fecal and urine fresh weight was $173 \pm$ $46 \mathrm{~g}$ and $1701 \pm 271 \mathrm{~g}$, respectively.

Data on apparent absorption, urinary excretion, and apparent retention for ${ }^{74} \mathrm{Se}$-selenite and ${ }^{76} \mathrm{Se}$-selenate are summarized in Table 1. Mean apparent absorption was $97.1 \%$ for ${ }^{76} \mathrm{Se}-$ selenate and $73.4 \%$ for ${ }^{74} \mathrm{Se}$-selenite. The mean difference was $23.7 \%$ (range: $13.8 \%-35.7 \%$; SD $6.8 \% ; p<0.001$ ). The mean urinary excretion ( $\%$ of ingested dose) was $36.4 \%$ for ${ }^{76} \mathrm{Se}-$ selenate and $9.7 \%$ for ${ }^{74} \mathrm{Se}$-selenite, with a mean difference of $26.7 \%$ (range: $13.9 \%-36.5 \%$; SD $5.9 \%$; $p<0.001$ ). The mean urinary excretion during the first $24 \mathrm{~h}$ ( $\%$ of total urinary excretion) was $82.3 \%$ for ${ }^{76} \mathrm{Se}$ and $47.8 \%$ for ${ }^{74} \mathrm{Se}$, with a mean

\begin{tabular}{|c|c|c|}
\hline & ${ }^{74}$ Se-selenite & ${ }^{76}$ Se-selenate \\
\hline Apparent absorption (\%) & $\begin{array}{l}73.4 \pm 5.8^{*} \\
(63.0-81.4)\end{array}$ & $\begin{array}{l}97.1 \pm 1.3 \dagger \\
(65.2-98.7)\end{array}$ \\
\hline Urinary excretion (\%) & $\begin{array}{l}9.7 \pm 2.8^{*} \\
(6.1-15.0)\end{array}$ & $\begin{array}{l}36.4 \pm 5.5 \dagger \\
(30.7-47.2)\end{array}$ \\
\hline Apparent retention (\%) & $\begin{array}{l}63.7 \pm 6.0^{*} \\
(54.9-70.6)\end{array}$ & $\begin{array}{l}60.7 \pm 5.6^{*} \\
(50.6-67.9)\end{array}$ \\
\hline
\end{tabular}

Values are mean \pm SD (range). Values in the same row not sharing a common superscript symbol are significantly different, $p<0.001$. difference of $34.5 \%$ (range: $23.1 \%-44.9 \%$; SD $6.8 \%$; $p<$ 0.001 ). The mean apparent retention of the two isotopes was not significantly different: $60.7 \%\left({ }^{76} \mathrm{Se}\right.$-selenate) versus $63.7 \%$ $\left({ }^{74} \mathrm{Se}\right.$-selenite). The mean difference was $-3.01 \%$ (range: $-14.0 \%-12.0 \%$; SD 9.4\%; $p=0.36$ ). Isotope enrichment of postbalance fecal samples was negligible, representing $1.1 \pm$ $0.9 \%$ and $2.0 \pm 1.8 \%$, respectively, of the total $72 \mathrm{~h}$ fecal excretion of ${ }^{74} \mathrm{Se}$ and ${ }^{76} \mathrm{Se}$.

Classical chemical balance data. The data for the classical chemical balance technique are summarized in Table 2. During the $72 \mathrm{~h}$ balance period, total selenium intake from the formula (native plus added stable isotope selenium) was $60.8 \pm 4.6 \mu \mathrm{g}$. Apparent selenium absorption was $45.6 \pm 5.2 \mu \mathrm{g}$ Se, corresponding to $75.7 \pm 5.4 \%$ of total selenium intake. Total urinary Se excretion was $21.0 \pm 11.4 \mu \mathrm{g}$ Se, representing 46.6 $\pm 11.4 \%$ of apparently absorbed selenium or $34.9 \pm 7.0 \%$ of total selenium intake. Mean apparent selenium retention was $24.7 \pm 7.0 \mu \mathrm{g} \mathrm{Se}$, corresponding to $40.8 \pm 11.1 \%$ of total selenium intake.

\section{DISCUSSION}

In the present study, $10 \mu \mathrm{g}$ of each selenium stable isotope were administered. The dose was based on both nutritional and analytical considerations, i.e. to evaluate selenium apparent absorption and retention at levels used for food fortification of infant formulas $(14,15,17,26)$ and to enable accurate determination of isotope enrichments in fecal and urine samples. Consumption of the labeled formulas approximately doubled the infants' daily selenium intake during the first $24 \mathrm{~h}$ of the study. The results from this study are thus relevant to apparent selenium retention and absorption from selenium-fortified infant formulas consumed by healthy term infants with plasma selenium in the same range as reported for formula-fed North American infants $(14,15,17)$.

The infants in this study retained approximately $60 \%$ of selenium added as selenite or selenate to a milk-based infant formula. Although apparent retention was similar for selenate and selenite, large differences were found in their apparent absorption and urinary excretion. These results are similar to our previous findings in adults, also using stable isotope methodology (27). In the previous study, mean retention of $41 \%$ and $46 \%$ from selenite and selenate, respectively, added to the same milk-based formula was found. Fractional selenium retention from both compounds was higher in infants than in adults, possibly because of the higher selenium requirements and lower dietary selenium intake during infancy.

Table 2. Results based on chemical balance data: Apparent selenium absorption, urinary excretion and apparent retention of total selenium from a milk based infant formula labeled with

${ }^{74} \mathrm{Se}$-selenite and ${ }^{76} \mathrm{Se}$-selenate fed to nine full term infants

$\begin{array}{ll}\text { Total Se intake }(\mu \mathrm{g}) & 60.8 \pm 4.6(53.4-67.0) \\ \text { Apparent Se absorption }(\mu \mathrm{g}) & 45.6 \pm 5.2(36.2-53.3) \\ \text { Apparent Se absorption }(\%) & 75.7 \pm 5.4(67.8-84.1) \\ \text { Total urinary Se excretion }(\mu \mathrm{g}) & 21.0 \pm 4.2(14.7-26.3) \\ \text { Urinary Se excretion }(\% \text { of intake) } & 34.9 \pm 7.0(25.1-42.8) \\ \text { Apparent Se retention }(\mu \mathrm{g}) & 24.7 \pm 7.0(13.7-34.5) \\ \text { Apparent Se retention }(\%) & 40.8 \pm 11.1(25.7-59.0)\end{array}$

Values are mean $\pm \mathrm{SD}$ (range). 
In the present study, apparent absorption of selenate (91\%) was almost double that of selenite $(50 \%)$. The intraindividual variation in selenium absorption was larger for selenite $(\mathrm{CV}$ $8 \%$ ) than for selenate (CV 1\%), which is in agreement with earlier data in adults (27). Higher absorption of selenate as compared with selenite from infant formula has been reported in suckling rats, presumably owing to more efficient absorption of selenate in the small intestine (28). Selenate has been demonstrated to be absorbed by a saturable transport mechanism of the ileal mucosa (29), facilitated by the transmembrane $\mathrm{Na}^{+}$gradient across the intestinal brush border (30). Thus, a rapid transport across the brush border by a carrier-mediated mechanism $(29,31)$ was found for selenate, whereas selenite was absorbed by passive diffusion and showed a strong tendency to bind to the brush border (31).

Renal clearance is the major pathway for excretion of absorbed selenium $(32,33)$. Our data in term infants showed that urinary selenium excretion of the absorbed dose was 3-fold higher for selenate $(38 \%)$ than for selenite $(13 \%)$. Urinary excretion of selenium absorbed as selenate was very rapid; $80 \%$ of total urinary selenium excretion was excreted within $24 \mathrm{~h}$ after administration, compared with $48 \mathrm{~h}$ for selenite. Elevated and rapid urinary excretion of absorbed selenate has been reported in adults $(27,34)$ and is most likely related to the faster absorption and metabolism of selenate compared with selenite. Very limited information is available on the metabolic handling of absorbed selenate and selenite. Selenite has been shown to be rapidly taken up by erythrocytes, metabolized, and effluxed into plasma bound to albumin (35). To our knowledge, no information is available on the metabolism of newly absorbed selenate.

Since approximately $60 \%$ of selenium was apparently retained by term infants from formula fortified with selenate or selenite, it can be assumed that the effect of either compound on selenium nutritional status would be similar. This assumption is supported by the finding that selenite and selenate supplementation resulted in similar increases in platelet GPx activity in Finnish men (36). Although no direct comparison has been performed on the effect of these two selenium compounds on selenium status in infants, feeding infant formulas fortified with selenite (13-16) or selenate (17) improved plasma selenium level and plasma GPx activity in term infants.

Mean apparent selenium absorption measured by classical chemical balance technique was $76 \%$ of total selenium ingested during $72 \mathrm{~h}$. Urinary selenium excretion was high and represented almost half of the apparently absorbed selenium, resulting in a mean apparent selenium retention of $41 \%$. The intraindividual variation in apparent retention was high (range: $26 \%-59 \%$ ), reflecting the large variation in urinary selenium excretion (CV 20\%). For comparison, Ehrenkranz et al. (19) reported mean apparent absorption of $68 \%$ and mean apparent retention of $53 \%$ of total selenium from preterm formula fortified with selenite in very low birthweight infants.

A selenium compound used for fortification of foods consumed by population groups at risk of low selenium intake, such as infants and patients with chronic or acute diseases, should ensure adequate absorption and retention of selenium. Therefore, fortification of nutritional products with selenate may be considered to be more efficient than selenite for these population groups. A number of aspects of selenate absorption and utilization favor the use of selenate versus selenite, including the higher fractional absorption, as compared with selenite, observed in the present study as well as in previous human studies $(27,34)$ and in suckling rats $(28)$. In addition, the high and rapid urinary excretion of selenium absorbed from selenate can be considered an advantage over selenite for maintaining selenium homeostasis. However, selenate may be less suitable for infants with renal dysfunction or preterm infants with immature renal function, because urinary excretion of absorbed selenium is essential for homeostatic control of body selenium. In addition, concerns have been raised about the potential pro-oxidative properties of selenite and its lower stability compared with selenate when added to foods (37). Although these concerns need to be further investigated, they are additional factors potentially in favor of the use of selenate for selenium fortification of foods.

In conclusion, our results indicate that selenite and selenate were equally well retained by healthy term infants, although large differences in apparent absorption and urinary excretion were observed. Thus, the nutritional impact of infant formulas fortified with either of these inorganic selenium compounds can be expected to be similar in healthy term infants. Differences in the metabolism of these two inorganic selenium compounds may favor the use of selenate.

Acknowledgments. The authors thank K. Longet, S. Metairon, and J. Clough for expert technical assistance, R. Hurrell (ETH Zürich, Switzerland) and P. Kastenmayerfor the advice, and R. Muñoz-Box and M. Baumgartner at the Nestlé Research Center for statistical evaluation. We also thank the nursing staff at the Fomon Infant Nutrition Unit for expert technical assistance and subjects and their parents for their participation.

\section{REFERENCES}

1. National Research Council 1989 Recommended Dietary Allowances, 10th ed. National Academy Press, Washington, DC, pp 217-224

2. World Health Organization 1996 Trace elements in human nutrition and health. WHO, Geneva, pp105-122

3. Arner ESJ, Holmgren A 2000 Physiological functions of thioredoxin and thioredoxin reductase. Eur J Biochem 267:6102-6109

4. Zhong L, Arner ESJ, Holmgren A 2000 Structure and mechanism of mammalian thioredoxin reductase: the active site is a redox-active selenothiol/selenosulfide formed from the conserved cysteine-selenocysteine sequence. Proc Natl Acad Sci USA 97:5854-5859

5. Zachara BA 1993 Mammalian selenoproteins. J Trace Elem Health Dis 6:137-151 6. Beck MA 1996 The role of nutrition in viral disease. J Nutr Biochem 7:683-690

7. Clark LC, Combs GF, Turnbull BW 1996 Effects of selenium supplementation for cancer prevention in patients with carcinoma of the skin. J Am Med Assoc 276:19571963

8. Litov R, Combs G 1991 Selenium in pediatric nutrition. Pediatrics 87:339-351

9. Lombeck I, Kasperek K, Bonnermann B, Feinendegen LE, Bremer HJ 1978 Selenium content of human milk, cow's milk and cow's milk infant formulas. Eur J Pediatr 129:139-145

10. Roekens E, Robberecht H, Van Caillie-Bertrand M, Deelstra H, Clara R 1985 Daily intake of selenium by bottle-fed infants in Belgium. Eur J Pediatr 144:45-48

11. Robberecht H, Roekens E, Van Caillie-Bertrand M, Deelstra H, Clara R 1985 Longitudinal study of selenium content in human breast milk in Belgium. Acta Paediatr Scand 74:254-258

12. Sanz Alaejos M, Diaz Romero C 1995 Selenium concentration in milk. Food Chem 52:1-18

13. Kumpulainen J, Salmenperä, Siimes MA, Koivistoinen P, Lehto P, Perheenputa J 1987 Formula feeding results in lower selenium status than breast-feeding or selenium supplemented formula feeding: a longitudinal study. Am J Clin Nutr $45: 49-53$ 
14. McGuire MK, Burgert SL, Milner JA, Glass L, Kummer R, Geering R, Boucek R, Picciano MF 1993 Selenium status of infants is influenced by supplementation of formula or maternal diets. Am J Clin Nutr 58:643-648

15. Johnson CE, Smith AM, Chan GM, Moxeur-Mileur LJ 1993 Selenium status of term infants fed human milk or selenite-supplemented soy formula. J Pediatr 122:739-741

16. Darlow B, Inder T, Sluis KB, Nuthall G, Mogridge N, Winterbourn CC 1995 Selenium status of New Zealand infants fed either a selenium supplemented or a standard formula. J Paediatr Child Health 31:339-344

17. Smith AM, Chen LW, Thomas MR 1995 Selenate fortification improves selenium status of term infants fed soy formula. Am J Clin Nutr 61:44-47

18. Solomons NW, Torun B, Janghorbani M, Christensen MJ, Young VR, Steinke FH 1986 Absorption of selenium from milk protein and isolated soy protein formulas in preschool children: studies using stable isotope tracer ${ }^{74} \mathrm{Se}$. J Pediatr Gastroenterol Nutr 5:122-126

19. Ehrenkranz RA, Gettner PA, Nelli CM, Sherwonit EA, Williams JE, Ting BTG, Janghorbani M 1991 Selenium absorption and retention by very-low-birth- weigh infants: studies with the extrinsic stable isotope tag ${ }^{74} \mathrm{Se}$. J Pediatr Gastroenterol Nutr 13:125-133

20. Van Dael P, Van Cauwenbergh R, Deelstra H, Calomme M 1995 Determination of selenium in human serum by longitudinal Zeeman correction and flow injection hydride generation atomic absorption spectrometry. At Spectrosc 16:251-257

21. Fomon SJ 1993 Procedures for collection of urine and feces and for metabolic studies. In: Fomon SJ (ed) Nutrition of Normal Infants. Mosby, St. Louis, MO, pp 459-464

22. Van Dael P, Barclay D, Longet K, Metairon S, Fay LB 1998 Determination of selenium stable isotopes by gas chromatography-mass spectrometry with negative chemical ionisation. J Chromatogr B 715:314-317

23. Belsten JL, Smith AJA 1995 European Community -FLAIR common assay for whole-blood glutathione peroxidase (GSH-Px). Results of an interlaboratory trial. Eur J Clin Nutr 49:921-927

24. Turnlund JR, Keyes WR, Peiffer GL 1993 Isotope ratios of molybdenum determined by thermal ionisation mass spectrometry for stable isotope studies of molybdenum metabolism in humans. Anal Chem 65:1717-1722
25. Heiberger RM 1989 Computation for the analysis of designed experiments. Wiley, New York.

26. Litov RE, Sickles VS, Chan GM, Hargett IR, Cordano A 1989 Selenium status in term infants fed human milk or infant formula with or without added selenium. Nutr Res 9:585-596

27. Van Dael P, Davidsson L, Muñoz-Box R, Fay LB, Barclay D 2001 Selenium absorption and retention from a selenite or selenate-fortified milk-based formula in adult men measured by a stable isotope technique. Brit J Nutr 85:157-163

28. Lönnerdal B, Glazier CE, Lien EL 1992 Selenium supplementation of infant formula: uptake and retention of various forms of selenium in suckling rats. J Nutr Biochem $3: 644-652$

29. Wolffram S, Arduser F, Scharrer E 1985 In vivo intestinal absorption of selenate and selenite by rats. J Nutr 115:454-459

30. Arduser F, Wolffram S, Scharrer E 1985 Active absorption of selenate by rat ileum. J Nutr 115:1203-1208

31. Vendeland SC, Butler JA, Whanger PD 1992 Intestinal absorption of selenite, selenate, and selenomethionine in the rat. J Nutr Biochem 3:359-365

32. Oster A Prellwitz W 1990 The renal excretion of selenium. Biol Trace Elem Res 24:119-146

33. Whanger PD 1998 Metabolism of selenium in humans. J Trace Elem Exp Med 11:227-240

34. Thomson CD, Robinson MF 1986 Urinary and fecal excretions and absorption of a large supplement of selenium: superiority of selenate over selenite. Am J Clin Nutr 44:659-663

35. Suzuki KT, Shiobara Y, Itoh M, Ohmichi M 1998 Selective uptake of selenite by red blood cells. Analyst 123:63-67

36. Alfthan G, Aro A, Arvilommi H, Huttunen JK 1991 Selenium metabolism and platelet glutathione peroxidase activity in healthy Finnish men: effects of selenium yeast, selenite, and selenate. Am J Clin Nutr 53:120-125

37. Smith AM, Chan GM, Moxeur-Mileur, LJ Johnson CE, Gardner BR 1991 Selenium status of preterm infants fed human milk, preterm formula, or selenite-supplemented preterm formula. J Pediatr 119:429-433 